\title{
MULTI-FREQUENCY RADIO INTERFEROMETRY ALGORITHM
}

\author{
Orlov V. V., Lytvynenko O. A., Galanin V. V. \\ URAN-4 Observatory of IRA NASU, Odessa, Ukraine, uran4@te.net.ua
}

\begin{abstract}
This article is a continuation of the work published in (Orlov, 2018). A method of multi-frequency beamforming of a radio interferometer is proposed. The model diagram is presented, which consists of two antenna arrays, filters, receivers and a signal summing circuit. The model works as follows. The signals received by the antennas pass through the narrow-band filters of the receiving devices, which are tuned to certain frequencies, after which they are subjected to multiplicative processing and weighted summation with their coefficients.
\end{abstract}

In this work, model the system of a radio interferometer based on multi-frequency signal processing, and study the possibilities of minimizing the level of side lobes of the antenna pattern (AP). It is shown that a decrease in the level of side lobes is possible due to the expansion of the frequency range or the application of signal processing from several clusters (antenna arrays), due to their summation in the interferometer circuit. For the case of three bases of the interferometer, consisting of the same antenna arrays, the total AP is calculated. In this case, a significant reduction of the side lobes to the level of the side lobes of a single antenna array is achieved. Further optimization of the radiation pattern can be carried out by choosing the frequency ranges of the interferometers and weights when summing the signals.

The proposed method makes it possible to adapt the interferometer AP due to time processing in frequency channels. The choice of the frequency grid and weighted multi-frequency signal processing provide a decrease in the level of side lobes and increase the resolution of the instruments. The application of the proposed algorithms will reduce the confusion effect from closely spaced radio sources. The computational possibilities of weighted processing are realized in real time, taking into account the rotation of the Earth, scanning the AP and angular arrangement of radio sources.

Keywords: antenna array, multiplicative processing, optimization, antenna pattern.

АНОТАЦІЯ. Ця стаття $€$ продовженням опублікованої роботи (Орлов та ін., 2018). Запропоновано метод многочастотного формування діаграми спрямованості (ДС) радіоінтерферометра. Представлена схема моделі, яка складається 3 двох антенних решіток, фільтрів, приймальних пристроїв i схеми підсумовування сигналів. Працює модель наступним чином. Прийняті антенами сигнали проходять через вузькосмугові фільтри приймальних пристроїв, які налаштовані на певні частоти, після чого піддаються мультипликативной обробці і вагового підсумовування зі своїми коефіцієнтами.

У роботі проводиться моделювання системи радіоінтерферометра на основі многочастотной обробки сигналів, досліджуються можливості мінімізації рівня бічних пелюстків ДС. Показано, що зменшення рівня бічних пелюсток можливо за рахунок розширення діапазону частот або застосування обробки сигналів від декількох кластерів (антенних решіток), за рахунок їх підсумовування в схемі інтерферометра. Для випадку трьох баз інтерферометра, що складається з однакових антенних решіток, розрахована сумарна ДС. В цьому випадку, досягається значне зниження бічних пелюсток до рівня бічних пелюсток одиночної антеною решітки. Подальша оптимізація ДС може здійснюватися вибором діапазонів частот інтерферометрів і вагових коефіцієнтів при підсумовуванні сигналів.

Запропонований метод дозволяє адаптувати ДС інтерферометрів за рахунок тимчасової обробки в частотних каналах. Вибір сітки частот i вагова многочастотна обробка сигналів забезпечують зниження рівня бічних пелюсток, підвищення роздільної здатності інструментів. Застосування запропонованих алгоритмів дозволить зменшити ефект сплутування від близько розташованих радіоджерел. Обчислювальні можливості ваговій обробки можуть бути реалізовані в реальному часі 3 урахуванням обертання Землі, сканування ДС i кутового розташування радіоджерел.

$\begin{array}{lrl}\text { Ключові слова: } & \text { антенна } & \text { решітка, } \\ \text { радіоінтерферометр, } & \text { оптимізація, } & \text { діаграма }\end{array}$
спрямованості.

\section{Introduction}

The development of the low-frequency range in radio astronomy is currently accompanied by a sharp increase in the number of new radio telescopes with large antenna arrays (LOFAR, LWA, GURT, NenuFAR, etc.). The purpose of these changes is to improving the quality of resolution when evaluating the parameters of space radio sources.

The desire for the effective use of decameter and lowfrequency meter wavelength ranges in radio astronomy leads to the need to improve hardware and algorithmic means. These improvements are necessary for: increasing the sample size of the signal when evaluating the parameters of celestial bodies, increasing noise immunity, 
as well as improving the quality of the antenna pattern (AP) with limited aperture sizes (Megn, 1997; Konovalenko, 2016). An effective way to increase the sample size of a signal is the property of the broadband signal, due to which, the accumulation of samples can be carried out at several frequencies (Megn, 2000; Shaw, 1965; Shepelev et al., 2017; Shepelev et al., 2019). In this case, it is necessary to take into account the dependence of the shape of the AP on the carrier frequency, especially the width of the main and side lobes. The development of digital technology for multi-frequency signal reception in the range of $10-200 \mathrm{MHz}$ also creates the prerequisites for the application of optimal algorithms for the formation of AP in real time without changing the apertures of the antennas of the radio interferometer.

This article proposes algorithms for optimizing AP by processing signals at several frequencies. The system of a radio interferometer is simulated on the basis of multifrequency signal processing, explores the possibility of minimizing the level of the side lobes of the AP.

\section{The model of the studied system}

The system under study based on multiplicative signal processing (fig. 1) consists of 2 antenna arrays $A P_{1}, A P_{2}$, the signals from whose outputs pass through are $\Phi_{1 l}$, $\Phi_{2 l}$ narrow-band filters $l=1, . ., L$ of receivers tuned to $\omega_{l}$ frequencies, then subjected to MP and weighted summation with coefficients $g_{l}$.

The model of a monochromatic point source of a signal from the outputs of a pair of filters of the $l$ frequency channel of two omnidirectional antennas can be represented as

$$
\begin{aligned}
& U_{1 l}(t)=U \exp \left\{j\left(\omega_{l}\left(t+t_{0}\right)+\varphi_{0 l}\right\}=\right. \\
& =U \exp \left\{j\left(\omega_{l} t+\varphi_{0 l}+\psi_{l}\right)\right\} \\
& \begin{aligned}
U_{2 l}(t)=U \exp \left\{j\left(\omega_{l}\left(t-t_{0}\right)+\varphi_{0 l}\right\}=\right. \\
=U \exp \left\{j\left(\omega_{l} t+\varphi_{0 l}-\psi_{l}\right)\right\}
\end{aligned}
\end{aligned}
$$

where $t_{0}$ - the delay time of arrival of the wave front along the aperture of MP, the size of which $d=\lambda / 2=\pi v / \omega$ is

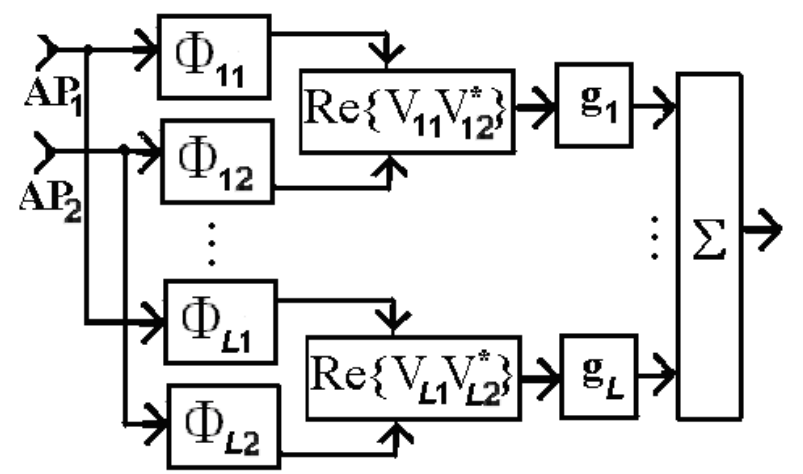

Figure 1: Radiometry system with multi-frequency processing matched with the wavelength $\lambda$, main (first) carrier frequency $\omega=\omega_{1}$, speed of wave propagation $v$, $\psi_{l}=\omega_{l} t_{0}=\pi\left(\omega_{l} / \omega\right) \cos \varphi-$ the phase of spatial delay of the wave front arrival at the frequency $\omega_{l}, \varphi-$ the angle of the wave front arrival relative to the normal of $A P$ base, $\varphi_{0}-$ the initial phase. It is assumed that in filters $\Phi_{1 l}$, $\Phi_{2 l}, \quad l=1, . ., L$, the amplitude, phase and mutual frequency distortions are eliminated to the accuracy of power leveling in frequency channels $P=P_{l}=\left\langle U_{1 l} * U_{2 l}\right\rangle, \quad l=1, . ., L$, where $<>$ are the averaging symbols of the process over time.

In (Orlov, 2018), a method for optimizing the weight processing of this model for radiometry is considered and it is shown that the level of side lobes can be reduced by more than $15 \mathrm{~dB}$ with a slight expansion of the main lobe of the antenna pattern.

3. Antenna pattern optimization of the multifrequency radio interferometer

The possibilities of lowering the level of the side lobes of the AP are investigated. The frequency response is formed by summing the signals from the outputs of the frequency channels of the interferometer in the frequency separation range (narrow, compared with the previous algorithm), with a deviation from the reference frequency The frequency response is formed by summing the signals from the outputs of the frequency channels of the interferometer in the frequency separation range (narrow, compared with the previous algorithm), with a deviation from the reference frequency $\omega=\omega_{1}$ within $(1 \ldots 1.5) \omega$. The output signals of adjacent equidistant $\mathrm{N}$ - element antenna arrays 1 and 2 at an arbitrary carrier frequency, taking into account (1), have the form

$$
\begin{aligned}
& U_{1 l}(t)=\sum_{i=1}^{N} U \exp \left\{j\left[\omega_{l}\left(t+t_{0}(i-1)\right]+\varphi_{0 l}\right\}=\right. \\
& =\sum_{i=1}^{N} U \exp \left\{j\left(\omega_{l} t+\varphi_{0 l}+(i-1) \psi_{l}\right)\right\}= \\
& =\frac{U \sin \left(N \psi_{l} / 2\right)}{\sin \left(\psi_{l} / 2\right)} \exp \left\{j\left(\omega_{l} t+\varphi_{0 l}+(N-1) \psi_{l} / 2\right)\right\} \\
& U_{2 l}(t)=\frac{U \sin \left(N \psi_{l} / 2\right)}{\sin \left(\psi_{l} / 2\right)} \exp \left\{j\left(\omega_{l} t+\varphi_{0 l}-(N-1) \psi_{l} / 2\right)\right\},
\end{aligned}
$$

where is $\psi_{l}=\omega_{l} t_{0}=\pi\left(\omega_{l} / \omega\right) \sin \varphi$ - the phase of the spatial delay of the arrival of the wave front at a frequency $\omega_{l}, \varphi-$ is the angle of arrival of the wave front relative to the normal to the $A P$, taking values in the interval $[-\pi / 2, \pi / 2]$. Then the output signal after summing the responses of the frequency channels is determined

$$
\begin{aligned}
U_{\text {out }} & =\operatorname{Re}\left\{U_{1, l} U_{2, l}^{*}\right\}= \\
& =U^{2} \sum_{l=1}^{L} g_{l}\left(\frac{\sin \left(N \psi_{l} / 2\right)}{\sin \left(\psi_{l} / 2\right)}\right)^{2} \cos \left\{\psi_{l}(N-1)\right\}
\end{aligned}
$$




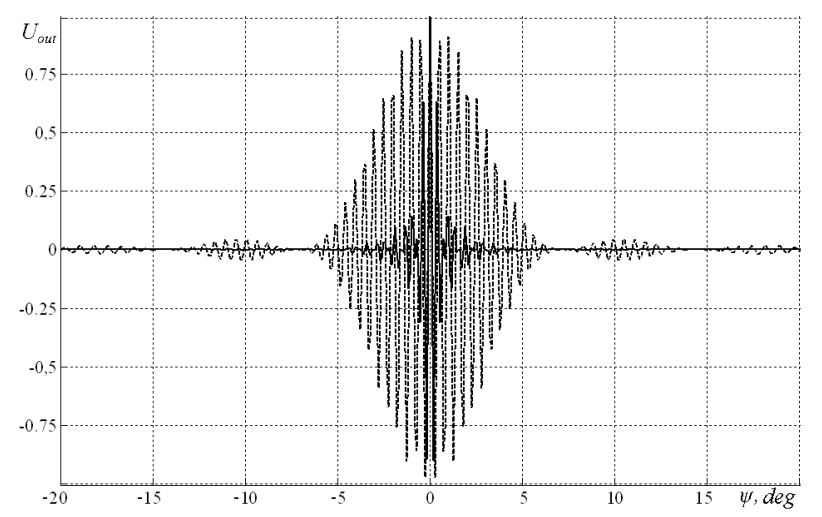

Figure 2: AP of the interferometer at one frequency and with averaging in the frequency range.

The output signal of equidistant $N$-element antenna arrays 1 and 2 (spaced a distance wich is $\mathrm{M}$ times more than the size of each antenna array) at an arbitrary carrier frequency, taking into account (1) - (3), has the form

$$
\begin{aligned}
U_{\text {out }} & =\operatorname{Re}\left\{U_{1, l} U_{2, l}^{*}\right\}= \\
& =U^{2} \sum_{l=1}^{L} g_{l}\left(\frac{\sin \left(N \psi_{l} / 2\right)}{\sin \left(\psi_{l} / 2\right)}\right)^{2} \cos \left\{\psi_{l} M(N-1)\right\}
\end{aligned}
$$

The formation of broadband AP is carried out by summing the signals from the outputs of the frequency channels (4), i.e. averaging over a frequency range from $\omega_{1}$ to $\omega_{2}$ with weighted constants $G^{T}=[1,1, . .1] / L$. Averaging is applied in the uniform grid of the frequency range $\omega_{L} / \omega_{1}=1,1, L=100$.

In Fig. 2 shows the radiation pattern of a radio interferometer consisting of two $\mathrm{N}=16$ elementary antenna arrays. The base between them is $\mathrm{M}=100$ times larger than the size of one antenna array. The dashed curve represent narrow-band AP at the same frequency, the full curve represent broadband AP. From the analysis of Fig. 2 it follows that a decrease in the level of side lobes (compared with narrow-band AP) is observed as they move away from the main lobe. At the same time, within 0.1 of the width of the main lobe of the antenna array (Fig. 3, expanded scale), the side lobes practically do not decrease - the first positive side lobe is -0.6 from the main. A decrease in their level is possible due to the expansion of the frequency range or the use of processing signals from several clusters (antenna arrays), for example, by summing these signals in an interferometer.

For the case of three bases of interferometers with sizes $\mathrm{M} 1=100 ; \mathrm{M} 2=125 ; \mathrm{M} 3=150$ calculated the total DN. The calculation was carried out in accordance with (4) and taking into account the same antenna arrays.

$$
U_{\text {out }}=\sum_{k=1}^{3} \sum_{l=1}^{L} g_{l}\left(\frac{\sin \left(N \psi_{l} / 2\right)}{\sin \left(\psi_{l} / 2\right)}\right)^{2} \cos \left\{\psi_{l} M_{k}(N-1)\right\} .
$$

Fig. 4 shows a fragment of the total AP. It shows a decrease in the side lobes to the level of the side lobes of a single antenna array used in the interferometer. Further optimization of the radiation pattern is carried out by choosing the frequency ranges of interferometers and weighting factors when summing the signals.

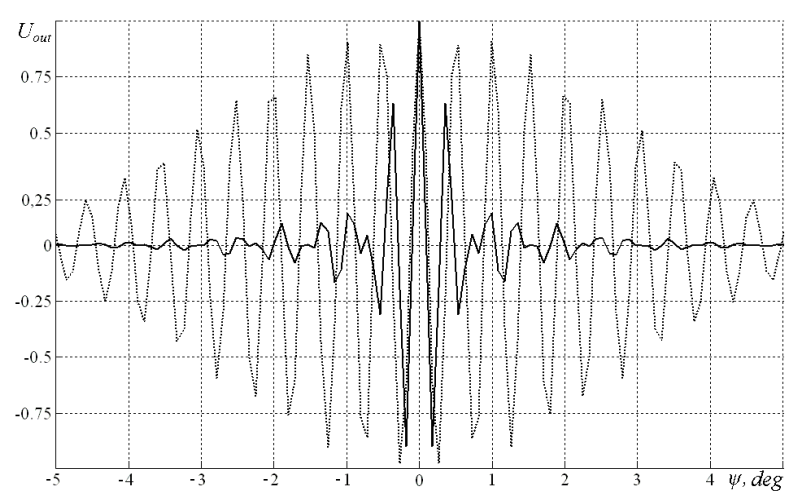

Figure 3: AP of the interferometer at the same frequency and when averaging in the frequency range (expanded scale).

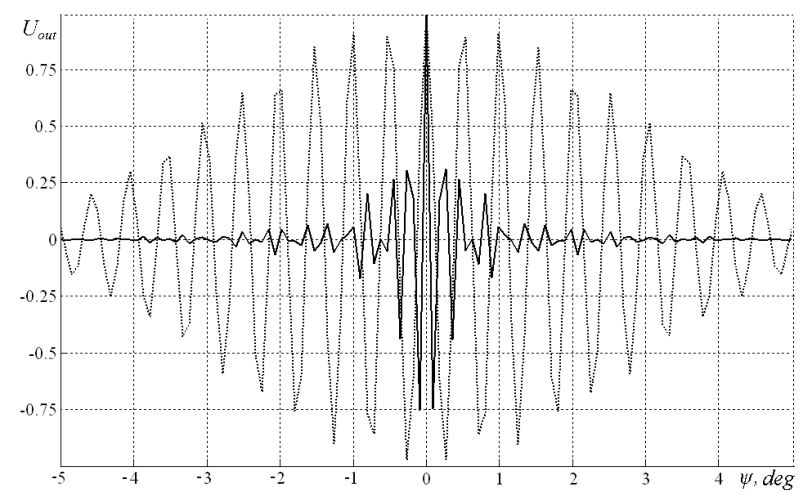

Figure 4: The total AP when summing the signals from the outputs of 3 interferometers (expanded scale).

\section{Conclusion}

The proposed approach extends the capabilities of radio interferometry in the formation of AP due to temporary processing in frequency channels. Due to weighted processing, the resolution of interferometers is increased, the confusion effect is reduced when receiving signals from closely located radio sources. In general, the choice of the frequency grid and weighted multifrequency signal processing provide a decrease in the level of side lobes, increase the resolution, and also reduce the influence of interference.

The computational capabilities of weighted processing are real-time, taking into account the rotation of the Earth, scanning the beam and the angular arrangement of radio sources...The computational capabilities of weighted processing may be carry out at real-time, taking into account the rotation of the Earth, beam scanning and the angular arrangement of radio sources.

\section{References}

Konovalenko A. et al.: 2016, Radio phys. Radio astron., 21, 2, 83. Megn A., Braude S., et al.: 1997, Radio phys. radio astron., 2, 4, 385.

Megn A, Braude S.: 2000, Radio phys. radio astron., 5, 1, 5.

Orlov V.V. et al.: 2018, Odessa Astron. Publ., 31, 137.

Shepelev V.A. et al.: 2017, Radio phys. radio astron., 22, 4, 247.

Shepelev V.A., et al.: 2019, 6th Gamow International Conference in Odessa: "New Trends in Cosmology, Astrophysics and HEP after Gamow" and 19th Gamow Summer School: "Astronomy and beyond: Astrophysics, Cosmology, Radioastronomy and Astrobiology", August 2019, Odessa, Program and Abstracts, 33.

Shaw E., Davis D.: 1965, Foreign Radio Electronics, 11, 103. 